\title{
An Empirical Evidence of International Fisher Effect in Bangladesh with India and China: A Time-Series Approach
}

\author{
Md. Mahmudul Alam* \\ PhD Student \\ Institute for Environment and Development (LESTARI) \\ Universiti Kebangsaan Malaysia (UKM) \\ 43600, Bangi, Selangor, Malaysia \\ Cell: +60162799091 \\ Email: rony000@gmail.com \\ Kazi Ashraful Alam \\ Manager \\ Dept. of Finance and Accounts, Milex Tires \\ Toronto, Ontario, Canada \\ Email: ashrafka35@gmail.com
}

\section{Anisuzzaman Shuvo}

Financial Officer

Sony Properties Ltd.

Dhaka, Bangladesh

Cell no. 01717436322

Email: zaman_mi6@hotmail.com

* Corresponding Author

\section{Citation Reference:}

Alam, M.M., Alam, K.A., and Shuvo, A. 2011. An Empirical Evidence of International Fisher Effect in Bangladesh with India and China: A Time-Series Approach, Elixir Online Journal: Elixir Finance, Vol. 36, pp. 3078-3081. Available at $<$ http://www.elixirjournal.org/articles view detail.php?id=999\&mode=pdf $>$.

This is a pre-publication copy.

The published article is copyrighted by the publisher of the journal. 


\title{
An Empirical Evidence of International Fisher Effect in Bangladesh with India and China: A Time-Series Approach
}

\begin{abstract}
This paper is an attempt to examine the empirical evidence of International Fisher Effect (IFE) between Bangladesh and its two other major trading partners, China and India. The IFE uses interest rate differentials to explain why exchange rates change over time. A time series approach is considered to trace the relationship between nominal interest rates and exchange rates in these countries. The estimated value, by applying OLS, is used to determine the casual relationship between interest rates and exchange rates for quarterly data from $4^{\text {th }}$ Quarter, 1995 to the $2^{\text {nd }}$ Quarter, 2008. The empirical results suggest that there is a little correlation between exchange rates and interest rates differential for Bangladesh with China and Bangladesh with India, and the relationship between the variables is also not noteworthy for Bangladesh. Further, the trends advocate that the forecasting of exchange rates with the hypothesis of IFE is not realistic for these countries.
\end{abstract}

Key Word: Purchasing Power Parity (PPP), Exchange Rate, Interest Rate, International Fisher Effect (IFS), Fisher Effect

\section{Introduction}

The Purchasing Power Parity (PPP) implies that exchange rates move to offset changes in inflation rate differentials among countries. Thus, a rise in the home country's inflation rate relative to those of other countries will be associated with a fall in the home currency's value. It will also be associated with a rise of interest rate of the home country relative to foreign interest rates. According to the Fisher Effect, the nominal interest rate in home country will also rise relative to the nominal interest rate of foreign country. Therefore, the adjustment of exchange rates to the nominal interest rate differentials between countries can result in either directly through flow of capital across international money markets, or through some sort of activity between the goods and money markets, where nominal interest rate differentials, on average, offset by exchange rate changes. Combination of these two conditions and the result is the International Fisher Effect (IFE).

The Fisher hypothesis says that the real interest rate in an economy is independent of monetary variables. Therefore, the real interest rate is equated across countries, then the country with the lower nominal interest rate would also have a lower rate of inflation and hence the real value of its currency would rise over time. In the absence of this proposition, investors tend to move money from countries with lower nominal interest rates to those with higher nominal interest rate, in order to obtain the highest rate of return on their deposits. This practice even extends to borrowing in the country with the lower nominal interest rate to deposit the money in the country with the higher nominal interest rate, because of the profitability (carry trade). These international money movement practices cause an increase in the value of the currency of the country with the higher nominal interest rate, which is contrary to the international Fisher effect. 
However, theoretically, the movement of capital from countries with low interest rate to countries with high interest rate would ultimately cause a movement in the exchange rate and will eliminate all profit opportunities. Thus, the nominal interest rate differentials can be an unbiased predictor of future changes in the spot exchange rate. This condition, still, does not mean that the interest differential is an especially accurate predictor; it just means that prediction errors tend to cancel out over time. The IFE says that the return on a foreign investment will be offset by an exchange rate change. Consequently, an investor that consistently purchases foreign assets will on average earn a similar return as if investing in purely domestic assets.

As far as trade relation is concerned, India was the second largest trade partner of Bangladesh, just after USA in 2003. However, recently China has emerged as the largest source of import for Bangladesh replacing India for the first time in 2006 (Table-1). The value of imported amount of Bangladesh was BDT 13.75b from China and BDT 12.41 b from India in 2005-2006 fiscal, where in 2004-2005 it was BDT 12.33b from India and BDT 6.94b from China. However, the statistical result of the study, PPP for Bangladesh with India and China (Alam et al. 2009) showed that the price of foreign country (India or China) had no significant impacts on bilateral exchange rate and the price of home country (Bangladesh) had opposite behavior that PPP warranted. For that reason, this paper is an attempt to see the shifting of trade towards China from India is beneficial to the Bangladesh economy by using the hypothesis of international Fisher effect.

Table 1: Common Commodity Imports by Bangladesh from China and India

\begin{tabular}{|c|c|c|c|c|}
\hline \multirow{2}{*}{ Group-wise Commodity } & \multicolumn{2}{|c|}{$\begin{array}{c}\text { China (BDT in } \\
\text { Millions })\end{array}$} & \multicolumn{2}{|c|}{$\begin{array}{c}\text { India }(B D T \text { in } \\
\text { Millions })\end{array}$} \\
\hline & $\begin{array}{l}2005- \\
2006\end{array}$ & $\begin{array}{c}2004- \\
2005\end{array}$ & $\begin{array}{c}2005- \\
2006\end{array}$ & $\begin{array}{l}2004- \\
2005\end{array}$ \\
\hline Cotton,(all types) cotton yarn/thread and cotton fabrics & 2,987 & 2,072 & 2,284 & 1,246 \\
\hline Boilers, Machinery and mechanical appliances, parts thereof & 2,094 & 1,595 & 994 & 1,147 \\
\hline $\begin{array}{l}\text { Electrical machinery and equipment and parts thereof, sound } \\
\text { recorders and reproducers, television image and sound recorders } \\
\text { and reproducers and parts and accessories of such articles }\end{array}$ & 1,334 & 636 & 323 & 302 \\
\hline Man-made staple fibers & 1,016 & 884 & 286 & 267 \\
\hline Knitted or crocheted fabrics & 857 & 665 & 91 & 93 \\
\hline $\begin{array}{l}\text { Vehicles other than railway or tramway, rolling stock and parts } \\
\text { and accessories thereof }\end{array}$ & 214 & 200 & 704 & 504 \\
\hline Plastics and articles thereof & 164 & 98 & 474 & 444 \\
\hline Cereals & 21 & 20 & 1,425 & 2,961 \\
\hline
\end{tabular}

Source: Bangladesh Bank (2004-2005, 2005-2006), Import Payments (annual), Department of Public Relations \& Publication, Dhaka, Bangladesh.

\section{Literature Review}

The long-run behavior of the ex ante real rate of interest is linked directly to the long-run relationship between inflation and nominal interest rates. The Fisher identity (Fisher, 1930) defines the ex ante real rate as the difference between the nominal rate and expected inflation. Thus, for the ex ante real interest rate to be affected only by transitory disturbances, any permanent shocks to the nominal interest rate and expected inflation must cancel out through the identity. Scholars such as Darby (1975) and Feldstein (1976) argue that the relationship is greater than one-to-one, while others such as Mundell (1963) and Tobin (1965) argue that the 
true relationship is less than one to-one. This is an important observation because recent research has found that both realized inflation rate and nominal interest rate are affected by permanent shocks. The long-run relationship between inflation rate and nominal interest rate using recent time-series techniques had been examined by the Evans and Lewis (1995), where it shows that nominal rate move less than one-for-one with inflation rate so that it appears to move permanently in ex post real interest rates. Coppock and Poitras (2000) examine on a larger sample $(\mathrm{N}=40)$ of countries, where they finds some support for a partial Fisher Effect rather than the support for full Fisher Effect.

Evidence from the study of Cloninger (2003) to measure the extent of the Fisher Effect across countries suggests the presence of the full Fisher Effect across a large number of countries. The other empirical support for the long-run Fisher effect has been mixed (e.g., Weber 1994, King and Watson 1997, Koustas and Serletis 1999, Rapach 2003). Empirical studies of the long-run Fisher effect have employed variations of the Fisher and Seater (1993) or by the FS approach. This approach argues that a permanent change in inflation has not taken place; instead, inflation is a mean-reverting, long-memory, fractionally integrated process. The study also stated that a reduced-form test of the long-run Fisher effect will be invalid and any inference as to whether the hypothesis holds or not will be unsupported. On the other hand, when examined the empirical evidence of Fisher's effect, the results (Uddin, Alam, and Alam, 2008) suggested that there were no existence of any co-movement of inflation with interest rates and the relationship between the variables is also not significant for Bangladesh. Further, the trends advocate that the inflation premium, equal to expected inflation that investors add to real-risk free rate of return, is ineffective in the country. The result analysis revealed that the inflation rate in Bangladesh was not highly correlated with the interest rate and the trend of inflation was increasing. As inflation had no significant relationship with interest rate and inflation is not depended on interest rate, government mechanism for calculating the inflation based on interest rate did not work properly in case of Bangladesh.

Aliber and Stickney (1975) calculated the percentage deviation from the Fisher effect for thirteen countries, constituting both developed and developing countries for the period of 1966-71. They used the average annual deviation as a measure for long-term validity and maximum annual deviation as a measure for short-term validity. They concluded that the international Fisher effect holds in the long run because the average annual deviation tended to be zero. The current international monetary system can be described as a hybrid system, where the basic market mechanisms for establishing exchange rates include the free float, managed float, target-zone arrangement and fixed-rate system. This system has led to rapidly fluctuating exchange rates, creating both problems and opportunities for actors dealing with foreign currencies (Shapiro 1998, p 55-56). However, in this examination, all three countries' (Bangladesh, China and India) currencies are pegged exchange rate against dollar. Eichengreen (1996, p-188) stated that the rise of the international capital mobility has made it difficult for many governments to defend their fixed or pegged exchange rates or even pursue independent macroeconomic policies.

Robinson and Warburton (1980) disputed the validity of the international Fisher effect. They argued that according to the Fisher effect the possibility to earn a higher interest return would be eroded in the medium term by the appreciation of the currency with the lower interest rate relatively to the currency with the higher interest rate. They concluded that superior returns could be earned and therefore argued that the international Fisher effect does not hold empirically. The maximum annual deviation was however too large to support the theory in 
the short run. Another study indicating a long-run tendency for interest differentials to offset exchange rate changes were made by Giddy and Dufey (1975).

\section{Data and Methodology}

The data of this paper consists of quarterly nominal interest rates for Bangladesh, India and China, and quarterly bilateral exchange rates between Bangladeshi Take with two other currencies- Indian Rupee and Chinese Yen for the years of 1995-2008. The data has been collected from OANDA, the currency sites. The quarterly exchange rates are market rates, which are largely determined by market forces.

The definitions of the nominal interest rates for three countries are Bangladesh: 3 months Schedule Bank Deposit rate, China: 3 months Deposit rate, India: 3 months Bank rate. Interest rate data have been collected from International Monetary Fund's: International Financial statistics. The collected data material has then been revised by calculating the percentage nominal interest differential and the percentage exchange rate change for different quarters and different country pairs, where Bangladesh is the home country.

The nominal interest differential has been computed by taking the Bangladesh's nominal interest rate minus the foreign nominal interest rate divided by one plus the foreign nominal interest. The equation for International Fisher Effect:

$$
\begin{aligned}
\left(S_{t+1}-S_{t}\right) / S_{t}=\left(r_{h, t}-r_{f, t}\right) /\left(1+r_{f, t}\right) \\
\text { Where, } \quad S_{t+1}=\text { exchange rate at time } t+1 \\
S_{t}=\text { exchange rate at time } t \\
r_{h t}=\text { nominal interest rate of home country } \\
\quad r_{f t}=\text { nominal interest rate of foreign country }
\end{aligned}
$$

The exchange rate change contains the exchange rate change from one quarter to another where the exchange rate is expressed as foreign currency units per US dollar. It has been computed by taking the exchange rate at time $t+1$ minus the exchange rate at time $t$, divided by the exchange rate at time $t$. If the foreign nominal interest rate, $r_{f}$ is relatively small can equation be approximated by following equation:

$$
R_{h}-R_{f}=\left(S_{t+1}-S_{t}\right) / S_{t}
$$

Where, $\mathrm{R}_{\mathrm{h}}=$ nominal interest rate of home country

$\mathrm{R}_{\mathrm{f}}=$ nominal interest rate of foreign country

$\mathrm{S}_{\mathrm{t}+1}=$ exchange rate at time $\mathrm{t}+1$

$\mathrm{S}_{\mathrm{t}}=$ exchange rate at time $\mathrm{t}$

These nominal interest differentials should, according to the International Fisher Effect, on average be offset by exchange rate changes. This approximation of the International Fisher Effect will get by subtracting 1 from both sides of equation (Shapiro 1998, p 171).

If $r_{h}>r_{f}$, it can expect an appreciation of the foreign currency and if $r_{h}<r_{f}$, it can expect a deprecation of the foreign currency. The parity line can be drawn from a line lies in 45 degrees in between the expected change in home currency value of foreign currency that is $y$ axis and nominal interest differential in favor of home country's $\mathrm{x}$ axis. On that parity line all 
points for which, $\mathrm{r}_{\mathrm{h}}-\mathrm{r}_{\mathrm{f}}=\left(\mathrm{S}_{\mathrm{t}+1}-\mathrm{S}_{\mathrm{t}}\right) / \mathrm{S}_{\mathrm{t}}$ and consequently shows all equilibrium points (Shapiro 1998, p 171-172).

The regressions use Ordinary Least Squares estimates of Alfa $(\alpha)$ and Beta $(\beta)$. Interpreted literally, shows the value of the exchange rate change when there is no nominal interest differential. When $\beta$ equals some values other than 0 , it means that a 1 percent increase in the nominal interest differential will lead to a that percentage offsetting change in the exchange rate. That is, if the nominal interest rate is one percent higher in the India than in Bangladesh, the Indian Rupee will depreciate by one percent relatively to the Bangladeshi Taka.

\section{Result Analysis}

This chapter aims to test the theory of the International Fisher Effect empirically. The results include 51 observations for each country pair and a total of two country pairs.

Though the R-squared for Bangladesh with China turned out to be very low, whereas only below $0.1 \%$ of the quarterly changes in the Yen/BDT exchange rate can be explained by the nominal interest differentials between the countries, at a very high significant level the null is failed to accept means nominal interest differentials has significant impacts on the Yen/BDT exchange rate changes. The result also illustrates that a $1 \%$ increase in the nominal interest differential, on average, lead to approximately a $0.017 \%$ change in the Yen/BDT exchange rate. The constant value, in turn, says that if the nominal interests in the Bangladesh and China are the same, the change in the exchange rate would on average equal $-1.423 \%$.

Table 2: International Fisher Effect Regression Output

\begin{tabular}{|c|c|c|c|c|c|c|}
\hline Model & & Value & T-value & P-value & $\overline{\mathbf{R}^{2}}$ & $\overline{D W}$ \\
\hline \multirow{2}{*}{ Bangladesh with China } & Constant & -1.423 & -3.18 & 0.0026 & \multirow{2}{*}{0.0008} & \multirow{2}{*}{1.84} \\
\hline & Coefficient & 0.017 & 0.197 & 0.8443 & & \\
\hline \multirow{2}{*}{ Bangladesh with India } & Constant & -0.449 & -1.136 & 0.0261 & \multirow{2}{*}{0.0059} & \multirow{2}{*}{1.34} \\
\hline & Coefficient & -0.094 & -0.543 & 0.589 & & \\
\hline
\end{tabular}

The R-squared for Bangladesh with India turned out to be very low yet greater than Bangladesh with China. Though at a very high significant level the null is failed to accept means nominal interest differentials has significant impacts on the Rupee/BDT exchange rate changes, only $0.6 \%$ of the quarterly changes in the exchange rate can be explained by the nominal interest differentials. The result also illustrates that a $1 \%$ increase in the nominal interest differential leads to an approximately $-0.094 \%$ change in the Rupee/BDT exchange rate. The constant value of -0.449 implies that the Rupee would depreciate against the Bangladeshi Taka by approximately $0.449 \%$ if the Bangladesh with India nominal interest differential equals zero. 


\section{Graph-1: International Fisher Effect for Bangladesh and China}

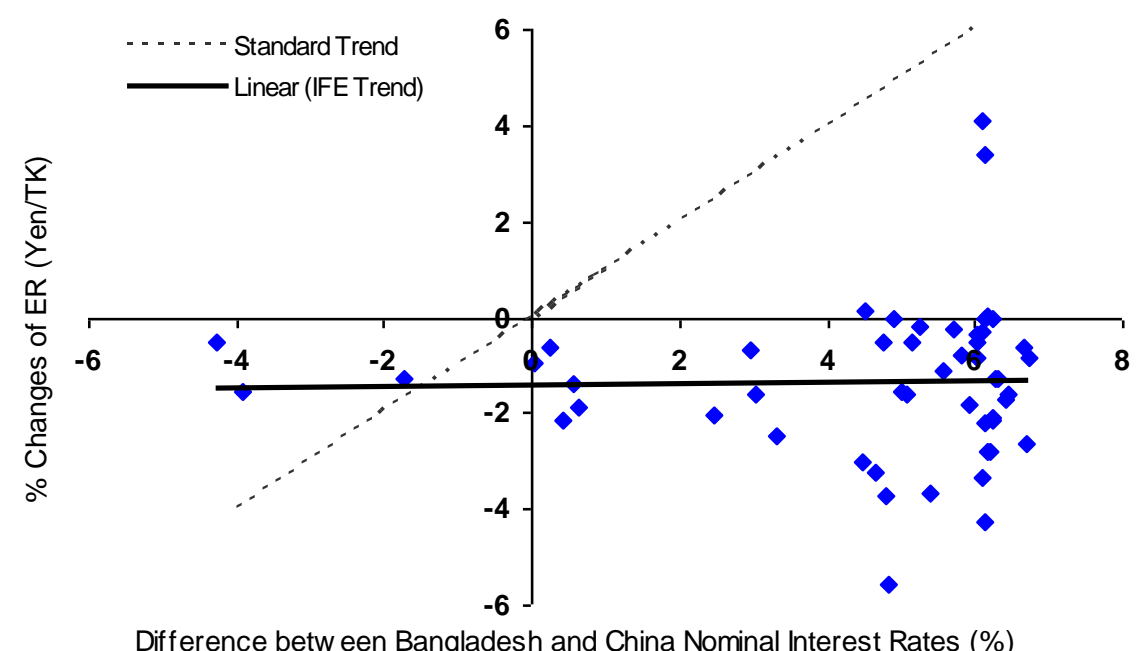

Graph-2: International Fisher Effect for Bangladesh and India

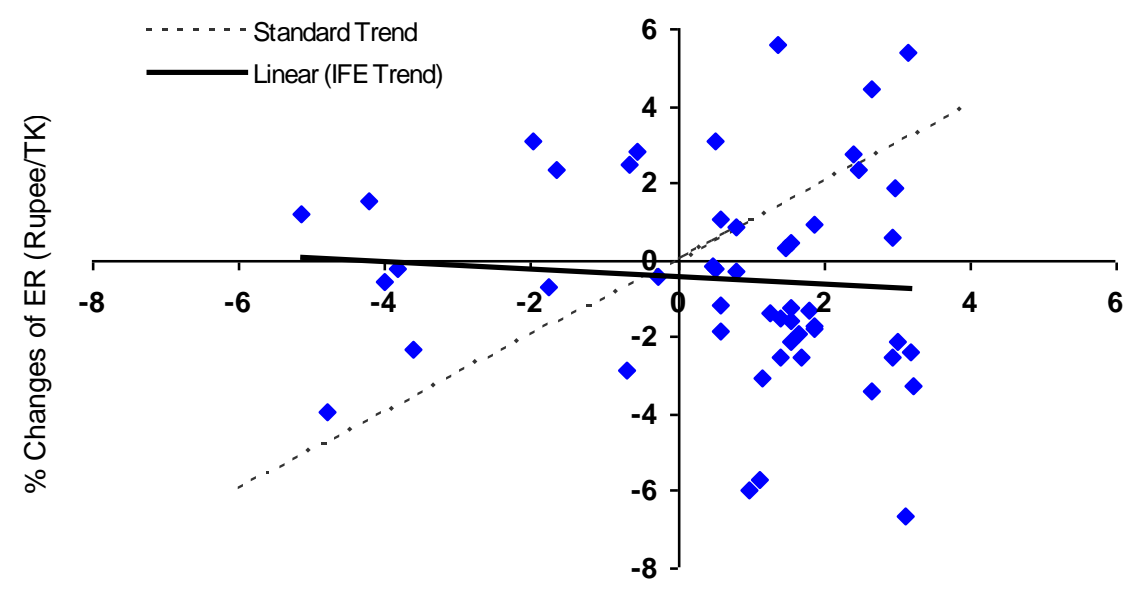

Difference betw een Bangladesh and India Nominal Interest Rates (\%)

The R-squared turned out very low for all country pairs. As the R squared is low for all studied country pairs, the nominal interest differentials should not be used to predict changes in future spot rate on a quarterly basis. Rather, prediction errors tend to cancel out over time. It can be concluded that the coefficient value cannot equal 1 for these country pairs, and therefore the nominal interest differentials cannot fully offset by exchange rate changes for these pair of countries.

\section{Conclusions}

The international Fisher effect does not hold for Bangladesh with India and Bangladesh with China during the investigated time period. The insignificant coefficient values show that the exchange rate movements react to other factors in addition to nominal interest differentials. It indicates that the money markets are not truly internationalized. There are many restrictions that prevent capital from freely flowing across borders to directly match nominal interest rate differentials. Examples of such factors are political risk, currency risk, transaction costs, taxes and psychological barriers. The exchange rate changes can also come through some sort of 
activity between the goods and money markets, some real cross-border investment activity or change in trade patterns in the goods market. It stills indirectly ensure nominal interest differentials, on average, that offset by exchange rate changes. It is possible that the changes in the nominal interest differentials have contained changes in real interest differentials. The observations also shows that the exchange rate sometimes has changed in the opposite direction as predicted by the theory, indicating a reaction to real interest differentials rather than relative inflationary expectations.

However, the International Fisher Effect theorem holds that real interest rates must be the same across borders and, capital markets must be integrated. It means that the capital must be allowed to flow freely across borders. However, in the developing countries like Bangladesh, China and India, it can be observed that the currency restrictions and other regulation, limit that integration. China has turned to a second largest trade partner of Bangladesh in 2006 replacing India, though; Chinese currency appreciates against Bangladesh currency. Thus, the empirical evidence now indicates that IFE does not hold very well in these trade partner countries.

\section{References}

Alam, K.A., Uddin, M.G.S., Alam, M.M., and Malakar, B, 2009, 'Trade Patterns of Bangladesh with India and China: An Empirical Evidence of the PPP Theory,' Journal of Regional Economic Studies, Vol. 2, pp. 26-34.

Aliber, R. Z, and Stickney, C. P, 1975, 'Accounting measures of foreign exchange exposure: the long and short of it,' Accounting Review, Vol. 50, No. 1, pp. 44-57.

Cloninger, D. O, 2003, 'The Fisher Effect: A Cross Country Empirical Analysis,' Available at SSRN: http://ssrn.com/abstract=466481 or DOI: $10.2139 /$ ssrn.466481

Coppock, L, and Poitras, M, 2000, 'Evaluating the Fisher Effect in the long-term crosscountry averages,' International Review of Economics and Finance, Vol. 9, No. 2, pp. 181-192.

Darby, M. R, 1975, 'The Financial and Tax Effects of Monetary Policy on Interest Rates,' Economic Inquiry, Vol. 13, pp. 266-276.

Eichengreen, B, 1996, Globalizing Capital, Princeton University Press: New Jersey.

Evans, M, and Lewis, K, 1995, 'Do Expected Shifts in Inflation Affect Estimates of the Long-Run Fisher Relation?' Journal of Finance, Vol. 50, pp. 225-253.

Feldstein, M, 1976, 'Inflation, income taxes, and the rate of interest: A theoretical analysis,' American Economic Review, Vol. 66, pp. 809-820.

Fisher, I, 1930, The Theory of Interest, New York: Macmillan.

Fisher, M, and Seater, J, 1993, 'Long-Run Neutrality and Super-neutrality in an ARIMA Framework,' American Economic Review, Vol. 83, pp. 402-415.

Giddy, I. H, and Dufey, G, 1975, 'The random behavior of flexible exchange rates: implications for forecasting'. Journal of International Business Studies, Vol. 6, No. 1, pp. 1-32.

King, R., and Watson, M, 1997, 'Testing long-run neutrality,' Economic Quarterly, Federal Reserve Bank of Richmond, Vol. 83, pp. 69-101.

Koustas, Z., and Serletis, A, 1999, 'On the Fisher effect,' Journal of Monetary Economics, Vol. 44, pp. 105-130.

Mundell, R, 1963, 'Inflation and Real Interest,' Journal of Political Economy, Vol. 71, pp. 280-83.

Rapach, D. E, 2003, 'International evidence of the long-run impact of inflation,' Journal of Money, Credit, and Banking, Vol. 35, pp. 23-48. 
Robinson, W, and Warburton, P, 1980, 'Managing currency holdings: lessons from the floating period,' London Business School Economic Outlook, pp. 18-27.

Shapiro, A. C, 1998, Foundations of Multinational Financial Management, Prentice-Hall Inc.: London.

Tobin, J, 1965, 'Money and Economic Growth,' Econometrica, Vol. 33, pp. 671-684.

Uddin, G. S., Alam, M. M. and Alam, K. A, 2008, 'An Empirical Evidence of Fisher Effect in Bangladesh: A Time-Series Approach,' ASA Business Review, Vol. 2, No. 1, pp. $1-8$.

Weber, A, 1994, 'Testing long-run neutrality: Empirical evidence for G7 countries with special emphasis on Germany,' Carnegie-Rochester Conference Series on Public Policy, Vol. 41, pp. 67-117. 